\title{
ANALYSIS OF EMPLOYEE SATISFACTION AND PERFORMANCE BASED ON THE CHARACTERISTICS OF COMPENSATION SYSTEMS AND ORGANIZATIONAL CULTURE IN HOSPITAL dr. SOEPRAOEN MALANG
}

\author{
Untung Slamet Suhariyono ${ }^{1}$ \\ ${ }^{1}$ Magister of Public Health Program, Stikes Surya Mitra Husada Kediri, Indonesia \\ Corresponding author: Untung Slamet Suhariyono (untungsuhariyono@gmail.com)
}

\begin{abstract}
This study aims to determine the effect of Employee Satisfaction and Performance based on the Characteristics of Compensation Systems and Organizational Culture in the Hospital of Dr. Soepraoen Malang. This study uses a quantitative research method research design. Data collected using a questionnaire on 100 permanent employee respondents at Soepraoen Hospital Malang.Independent variables of this study are Job Satisfaction and Employee Performance. The dependent variable of this study is the Compensation System and Organizational Culture. The results of the study show (1) Employee satisfaction has a significant influence on the compensation system; (2) Organizational culture has a significant influence on employee satisfaction; (3) Compensation has a significant influence on employee performance;(4) Organizational culture has a significant influence on employee performance; (5) Compensation has a significant effect on employee performance through employee performance satisfaction at the Hospital. II $d r$. Soepraoen; (6) Organizational culture has a significant influence on employee performance through employee performance satisfaction at the Tk Hospital. II dr. Soepraoen.
\end{abstract}

Keywords: Employee performance, employee satisfaction, compensation system and organizational culture

Copyright @ 2019 Stikes Surya Mitra Husada. All right reserved.

\section{INTRODUCTION}

The hospital is a complex health service provider institution. Hospital Law Number 44 of 2009 the hospital is a health service institution for the community with its own characteristics which are influenced by the development of health science, technological advances, and socio-economic life of the people who must be able to improve quality services. Human resources in an institution such as a hospital are important strategies to create an accelerated improvement in overall health status, integrated, equitable, affordable and acceptable to all societies. The availability of quality human resources is the main wealth, because without the availability of quality human resources, the activities of a government agency will not occur.

Employee performance is an accumulation of the individual performance of each employee in each field. If each individual's performance is good, then it can be ascertained that the company's performance will be good too (Javed, 2014). If the company wants good company performance, it must manage human resources well, especially identifying various factors that can influence employee performance. Workload is also needed to maintain motivation from employees and be more committed to the company. The more aspects in the work that are in accordance with the wishes of the individual, the higher the level of satisfaction felt. Job satisfaction can be formed by several factors both internal factors such as competence, stress, and work motivation and factors that originate from outside themselves such as organizational culture climate, work relations, communication patterns, compensation management, HR development programs and others (Mathis Dan Jackson, 2013). Giving compensation that is fair and in accordance with workload and responsibility is one of the right ways to motivate employees. 
In addition to compensation, other factors that affect job satisfaction and employee performance are organizational climate. According to Tagiuri and Litwin (in Wirawan, 2013: 121), the organizational culture climate is the quality of the organization's internal environment which is relatively ongoing, experienced by members of the organization, influencing their behavior and can be described in one organizational characteristic or characteristic.

\section{METHODS}

This study includes a descriptive method with a quantitative approach, namely the type of research to explain, summarize various conditions, various situations, or various variables that arise in the community that are the object of research based on what happened, in general this research uses inductive statistics to analyze research data (Bungin , 2013). The population in this study were employees who were status as permanent employees at Soepraoen Hospital Malang. The population in this study were 300 people(58 medical employees, 142 non-medical employees, 66 non-paramedic employees, 34 paramedic employees). The sampling technique that will be used in research this issaturated sampling.

Table 1 Sample Research

\begin{tabular}{clll}
\hline No. & Position & Population & Sample \\
\hline 1 & Pegawaimedis & 58 & 19 \\
\hline 2 & Non-medical staff & 142 & 47 \\
\hline 3 & Non-paramedic staff & 66 & 22 \\
\hline 4 & Employees of medical staff & 34 & 12 \\
\hline Total & & 300 & 100 \\
\hline
\end{tabular}

The data collection techniques used are the following methods: The survey method uses a questionnaire to obtain data directly from the object under study and the documentation method to obtain data about the number of employees at Soepraoen Hospital Malang. The analytical method used in this research are descriptive statistical analysis of obtained data on the respondents and the average - average as well as the presentation of the results of the questionnaire and inferential statistics Path analysis test. Steps to test Path analysisaccording to Riduwan and Kuncoro (2013) as follows:

1. Formulate hypotheses and structural equations

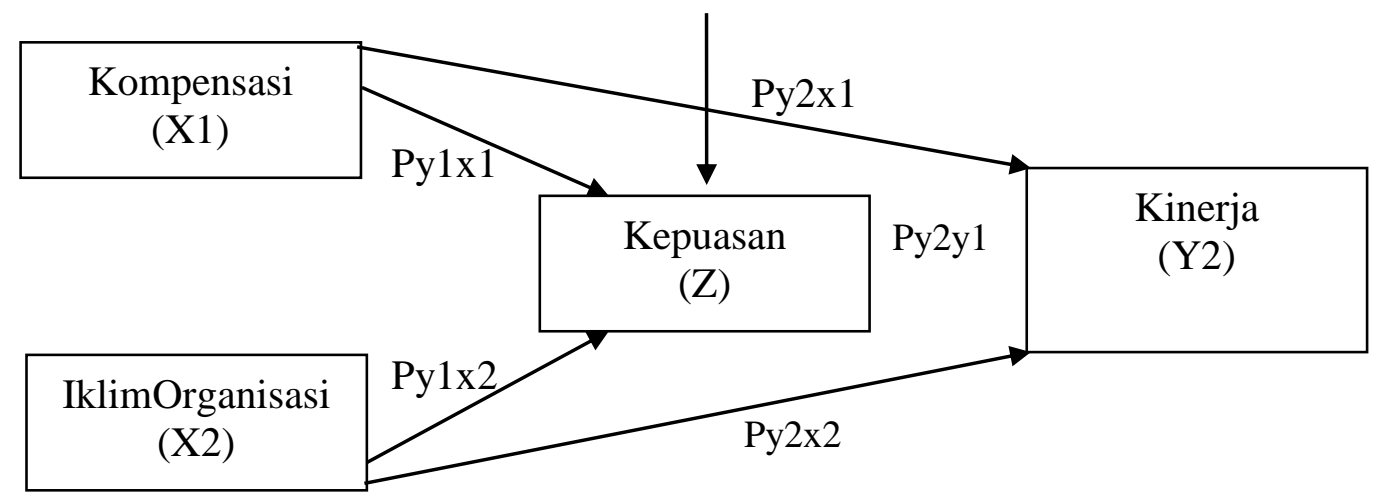

Figure 1 Model Hypothesis Path Diagram 
2. Calculate individual path coefficients

3. Summarize and Summarize

\section{RESULTS}

The results obtained are in accordance with the category of behavior variable values in the following table:

Table 2 Category of Variable Value of Compensation

\begin{tabular}{cllll}
\hline No. & Average value & Category & Total & Percentage \\
\hline 1 & $3.26-4.00$ & Very high & 54 & $54 \%$ \\
\hline 2 & $2.51-3.25$ & High & 32 & $32 \%$ \\
\hline 3 & $1.76-2.50$ & Enough & 8 & $8 \%$ \\
\hline 4 & $1.00-1.75$ & Low / low low & 6 & $6 \%$ \\
\hline Total & & & 100 & $100 \%$ \\
\hline
\end{tabular}

Data source: Primary data processed (2018)

Based on the results of the description that has been described, there is the highest mean value of 3.47, namely the indicator of the Soepraoen Hospital Employees get a pension benefit that is in accordance with their performance and position. While the lowest mean value is 3.04 , which is the indicator of the Soepraoen Hospital Employee getting insurance facilities to ensure employee welfare. As for the overall average value, the value of 3.23 is obtained in the good category.

The results obtained are in accordance with the category of organizational culturevariable values in the following table:

Table 3 Category Values of Variable Organizational Culture

\begin{tabular}{cllll}
\hline No. & Average value & Category & Total & Percentage \\
\hline 1 & $3.26-4.00$ & Sanga Tinggi & 45 & $45 \%$ \\
\hline 2 & $2.51-3.25$ & High & 43 & $43 \%$ \\
\hline 3 & $1.76-2.50$ & Enough & 6 & $6 \%$ \\
\hline 4 & $1.00-1.75$ & Low / low low & 6 & $6 \%$ \\
\hline Total & & & 100 & $100 \%$ \\
\hline
\end{tabular}

Data source: Primary data processed (2018)

The results of the study on cultural variables obtained the highest value at X2.2 with a value of 3.13 in the statement " felt the Soepraoen Hospital had attention to detail (Attention to detail) in the organizational culture carried out "the category is very high.Whereas, for the lowest value of the variable in the variable X2.5 amounted to 2.89 at the statement "feel the culture of organizations run in RS Soepraoen oriented team (Teamorientation)" in both categories. For the overall average, the average value is 3.06 in the high category. 
The results obtained are in accordance with the category of work satisfaction variable values in the following table:

Table 4 Categories of Variable Value of Job Satisfaction

\begin{tabular}{cllll}
\hline No. & Average value & Category & total & Percentage \\
\hline 1 & $3.26-4.00$ & Very high & 57 & $57 \%$ \\
\hline 2 & $2.51-3.25$ & High & 31 & $31 \%$ \\
\hline 3 & $1.76-2.50$ & Enough & 4 & $4 \%$ \\
\hline 4 & $1.00-1.75$ & Low / low low & 8 & $8 \%$ \\
\hline Total & & & 100 & $100 \%$ \\
\hline
\end{tabular}

Data source: Primary data processed (2018)

Based on table 4.10 above, it is known that out of the nine questions found in thevariable job satisfaction, the highest value is Y1.4 with a value of 3.33 in the statement "I feel the company has given fair and equal treatment without discriminating between ethnic groups, type sex, religion, disability, age and so on (discrimination practice) are in the very high category. While for the lowest score with an average of 3.02 found in indicator Y1.7 in the statement "I feel the company has provided training and education programs fairly " in the high category. The overall average value is 3.14 in the high category.

The results obtained are in accordance with the category of employee performancevariable values in the following table:

Table 5 Value Categories of Employee Performance Variables

\begin{tabular}{cllll}
\hline No. & Average value & Category & total & Percentage \\
\hline 1 & $3.26-4.00$ & Very high & 33 & $33 \%$ \\
\hline 2 & $2.51-3.25$ & High & 50 & $50 \%$ \\
\hline 3 & $1.76-2.50$ & Enough & 10 & $10 \%$ \\
\hline 4 & $1.00-1.75$ & Low / low low & 7 & $7 \%$ \\
\hline Total & & & 100 & $100 \%$ \\
\hline
\end{tabular}

Data source: Primary data processed (2018)

Based on table 5 above, it is known that from the five questions containedin the employee performance variable, the highest value is on the indicators Y2.2 and Y2.3 with a value of 3.11 in the statement "I completed the task well according to the responsibilities given by the company", and "I finish work on time and do not involve overtime" in the high category . Whereas for the lowest value at an average of 2.84 is in the indicator Y2.4 in the statement "I completed effective work in accordance with the existing budget and technological resources " in the high category. The overall average value is 2.94 in the high category. 
The normality test can also be seen using the Kolmogorov-Smirnov one-sample test.

Table 6 Normality Test Results

\begin{tabular}{cllll}
\hline No. & Variable & Kolmogorov-Smirnov Z & Asymp. Sig. (2-tailed) & Information \\
\hline 1 & Compensation & 2,176 & 0.543 & Normal \\
\hline 2 & Organizational culture & 2,279 & 0.186 & Normal \\
\hline 3 & Satisfaction & 2,628 & 0.745 & Normal \\
\hline 4 & Performance & 2,140 & 0.995 & Normal \\
\hline
\end{tabular}

From Table 6, the Kolmogorov-Smirnov $\mathrm{Z}$ value in the Compensation variable is 2.176 with a value of sig 0.543 greater than 0.05 . Thus it can be concluded that $\mathrm{H} 0$ is accepted and $\mathrm{H} 1$ is rejected, so it can be concluded that all residuals in the variable Compensation can be said to be normally distributed.

Furthermore, the magnitude of the Kolmogorov-Smirnov $\mathrm{Z}$ value on the organizational culture variable is 2,279 with a value of 0.186 sig greater than 0.05 . Thus, it can be concluded that $\mathrm{H} 0$ is accepted and $\mathrm{H} 1$ is rejected, so it can be concluded that all residuals can be said in the variable Organizational culture with normal distribution.

Furthermore, the magnitude of the Kolmogorov-Smirnov $\mathrm{Z}$ value on the Satisfaction variable is 2.628 with a value of $0.745 \mathrm{sig}$ greater than 0.05 . Thus it can be concluded that $\mathrm{H} 0$ is accepted and H1 is rejected, so it can be concluded that all residuals in the Satisfaction variable are normally distributed.

The magnitude of the Kolmogorov-Smirnov $\mathrm{Z}$ value on the Performance variable is 2.140 with a value of sig 0.995 greater than 0.05 . Thus it can be concluded that $\mathrm{H} 0$ is accepted and $\mathrm{H} 1$ is rejected, so it can be concluded that all residuals in the Performance variable can be said to be normally distributed.

The Heteroscedasticity test in this study is presented as follows:

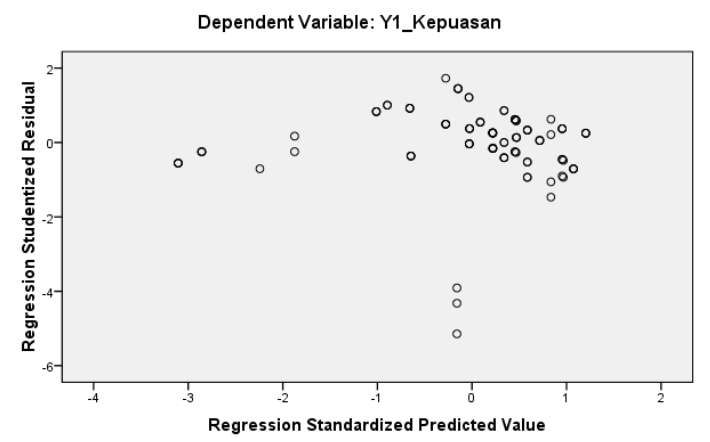

Figure 2 Heteroscedasticity Test Model 1 Effect of Compensation and Organizational Culture on Satisfaction

The heteroscedasticity test of the Compensation variable, Organizational Culture, on Satisfaction shows that the points are spread above and below zero. The points spread and did not form a certain pattern that is regular so that it can be concluded that the regression model did not occur heteroscedasticity. 




Figure 3 Heteroscedasticity Test Model 2 Effect of Compensation, Organizational Culture, Satisfaction with Performance

The variable heteroscedasticity test results of Compensation, Organizational Culture, Satisfaction with Performance shows that the points are spread above and below zero. The points spread and did not form a certain pattern that is regular so that it can be concluded that the regression model did not occur heteroscedasticity.

\section{Path Test Analysis Results}

Table 7 Training Variable Effect Pathways Coefficient Test Results Work (X1) and Organizational Culture (X2) Against Satisfaction (Y1)

\begin{tabular}{llll}
\hline Variable & Beta & t-count & P-Value \\
\hline Compensation & 0.570 & 6,892 & 0,000 \\
\hline Organizational culture & 0.485 & 5,446 & 0,000 \\
\cline { 1 - 2 } $\mathrm{r}^{2}=0.906$ & & \multirow{2}{*}{ Critical Value t-table $=2,000$} \\
\cline { 1 - 2 } $\mathrm{KD}=90.6$ & & \\
\hline
\end{tabular}

Source: Appendix 16

Table 7 shows that the test results of the influence of the Compensation variable (X1) and Organizational Culture (X2), on Satisfaction (Y1) have $r^{2}$ of 0.906 or the coefficient of determination (KD) of 90.6. This result explains that the results of testing the effect of variable compensation (X1) and organizational culture (X2) contributed $90.6 \%$ to the influence of satisfaction variables (Y1) .It is concluded show that satisfaction variables (Y1) is affected by the variable compensation (X1) is positive and significant and the Satisfaction variable (Y1) is influenced by the variable Organizational Culture (X2) positively and significantly .

Table 8 Varabel Compensation Pathway Coefficient Test Results (X1), Organizational Culture (X2) and Satisfaction (Y1), Against Performance (Y2)

\begin{tabular}{llll}
\hline Variable & Beta & t-count & P-Value \\
\hline Compensation & 0.159 & 2.162 & 0.045 \\
\hline Organizational culture & 0.858 & 10,992 & 0,000 \\
\hline Satisfaction & 0.112 & 2.438 & 0,000 \\
\hline $\mathrm{r}^{2}=0.939$ & Critical Value t-table $=2,000$ & \\
\hline $\mathrm{KD}=93.9$ & & \\
\hline
\end{tabular}

Source: Appendix 16 
Table 8 shows that the results of testing the effect of the variable Compensation (X1), Organizational Culture (X2) and Satisfaction (Y1) on Performance (Y2) have $r^{2}$ of 0.939 or the coefficient of determination (KD) of 93.9. This explains that the results of testing the influence of the Compensation variable (X1), Organizational Culture (X2) and Satisfaction (Y1) contribute 93.9\% to the Performance variable (X2). These results indicate that the Performance variable (Y2) is influenced by the Compensation variable (X1) positively and significantly; the Performance variable (Y2) is influenced by the variable Organizational Culture (X2) positively and significantly; and the Performance variable (Y2) can be explained or directly influenced by the Satisfaction variable (Y1) a summary of the path coefficients modeled in this study can be seen in table 9:

Table 9 Summary of Path Coefficients

\begin{tabular}{lllll}
\hline Exogenous Variable & Varabel Indogen & Beta coefficient & P-Value & Conclusion \\
\hline Compensation & Satisfaction & 0.570 & 0,000 & $\begin{array}{l}\text { Positive and } \\
\text { significant }\end{array}$ \\
\hline Compensation & Performance & 0.159 & 0.045 & $\begin{array}{l}\text { Positive and } \\
\text { significant }\end{array}$ \\
\hline Organizational culture & Satisfaction & 0.485 & 0,000 & $\begin{array}{l}\text { Positive and } \\
\text { significant }\end{array}$ \\
\hline Organizational culture & Performance & 0.858 & 0,000 & $\begin{array}{l}\text { Positive and } \\
\text { significant }\end{array}$ \\
\hline Satisfaction & Performance & 0.112 & 0,000 & $\begin{array}{l}\text { Positive and } \\
\text { significant }\end{array}$ \\
\hline
\end{tabular}

Source: Appendix 16

Based on the results of the path analysis calculations obtained, it can be described in the path equation model as follows:

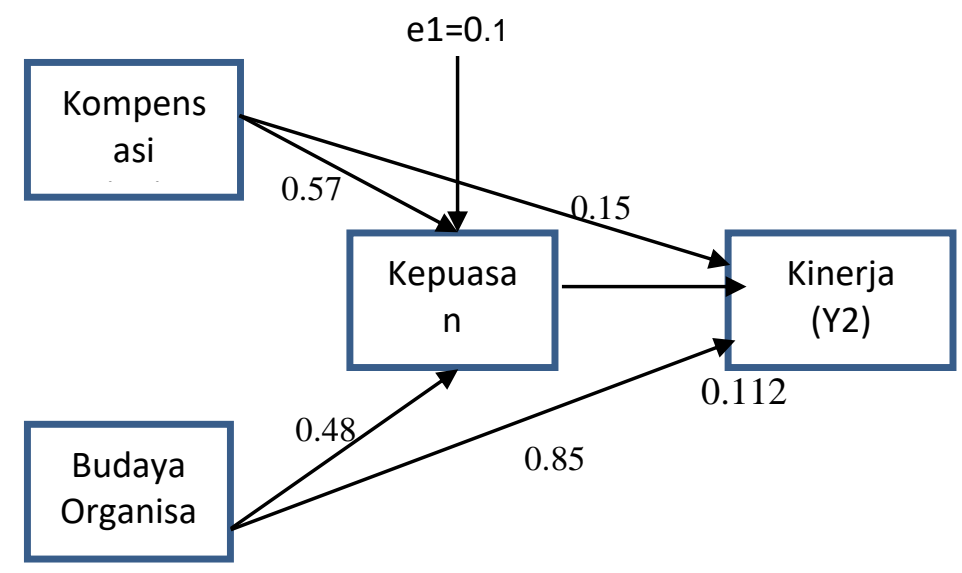

Figure 4 Pathway Analysis Results Model 
The results of calculation of direct and indirect influence served dala 4:17 amthe following table:

Table 10 Results of Testing Direct and Indirect Relations

\begin{tabular}{lll}
\hline Variable Influence & $\begin{array}{l}\text { Direct } \\
\text { Influence }\end{array}$ & $\begin{array}{l}\text { Indirect Effects Through } \\
\text { Y1 }\end{array}$ \\
\hline X1 (Compensation) against Y1 (Satisfaction) & 0.570 & - \\
\hline X1 (Compensation) against Y2 (Performance) & 0.159 & $\begin{array}{l}(0.570) \times(0.112)=0.063 \\
\text { (significant) }\end{array}$ \\
\hline X2 (organizational culture) towards Y1 (Satisfaction) & 0.485 & - \\
\hline X2 (organizational culture) towards Y2 (Performance) & 0.858 & $\begin{array}{l}(0.485) \times(0.112)=0.054 \\
\text { (significant) }\end{array}$ \\
\hline Y1 (Satisfaction) towards Y2 (Performance) & 0.112 & - \\
\hline
\end{tabular}

Source: Appendix 16

The results of statistical calculations show that the Compensation variable has a significant effect on the Satisfaction variable with a coefficient of 0.570 . The Compensation variable also has a significant effect on the Performance variable with a coefficient value of 0.159 . The Organizational Culture variable has a significant effect on the Satisfaction variable with a coefficient of 0.485 , and the Organizational Culture variable has a significant effect on the Performance variable with a coefficient of 0.858. While the Satisfaction variable has a significant effect on the Performance variable with a coefficient of 0.112 . The indirect test also shows that the two variables have an indirect and significant effect.

\section{DISCUSSION}

\section{A. Effect of Characteristics of the Compensation System on Employee Satisfaction}

The results of the study showed that the better the compensation system applied in Tk.II Soepraoen Hospital, the higher the level of employee satisfaction. Job satisfaction is a description of the attitude of an employee whether happy or unhappy about the benefits, work related to himself, with his boss, fellow employees, and his work environment. Mangkunegara (2013: 117) argues that job satisfaction is a feeling that supports or does not support employees who are related to their work or their condition.Employee job satisfaction can be increased by providing compensation in accordance with the workload and the level of position that the employee has.

Based on the results of the research, it can be seen that the better the compensation system applied to an agency, the greater job satisfaction will be. This is because job satisfaction is a psychological condition that is owned by a person related to the work they have. So that when an employee feels the compensation system provided by the agency to the employee is in line with expectations or even exceeds the expectations of the employee, the employee feels that the work has been valued by the agency.

The results of this study support the results of the research conducted by Siramiati et al (2016) which states that performance-based compensation has a significant influence on employee motivation and employee satisfaction. In addition, this study rejects the results of a study conducted by Salisu et al (2015) whose research results show that compensation does not significantly influence job satisfaction in Jigawa, Nigeria.

\section{B. Effect of Organizational Culture on Employee Job Satisfaction}

Organizational culture influences employee job satisfaction because organizational culture is an atmosphere and social interaction within an organization while humans are social beings who need to interact with one another, so that when an organization has a good organizational culture, employee satisfaction will increase because employee employees feel like they are working. 
The results of this study support the results of a study conducted by Ida Ariyani et al(2016) which states that organizational culture has a positive value and has a significant effect on nurse job satisfaction. on the other hand, this study rejects the results of research conducted by Susanty (2012) which shows that organizational climate does not have a significant influence on job satisfaction.

Based on the results of the research, it can be seen that the better the organizational culture possessed by an agency, the greater job satisfaction will be. this is because a good organizational culture can lead to a feeling of emotional closeness among employees so that employee satisfaction with the work culture in the agency will be better.

\section{Effect of Compensation on Employee Performance}

Compensation is something that is received by employees as part of the reward for their work. Compensation will provide satisfaction and motivation for employee performance. According to Jahrie and Hariyoto (2014) compensation is a reward received by an employee or worker from his company as a result of the services / energy he has given to the company. In line with the compensation function according to Samsuddin (2016: 188), namely the allocation of human resources efficiently. This function shows that giving compensation to employees who excel will encourage them to work better. This shows a good relationship to compensation for employee performance.Mondy (2013: 4) states that if the compensation program is set large enough, the procurement of qualified employees for the company will be easier, meaning that employees will perform according to the company's goals.

Based on the results of the research, it can also be seen that the better the compensation applied to an agency, the better the employee's performance. This is because performance is a work result of someone who can be influenced by external factors including the effect of compensation. Similarly, the purpose of compensation is to be able to provide both moral and moral support and motivation to employees so that they remain enthusiastic in carrying out their work, so that employees are able to produce or create good performance or good performance.

The results of this study support the results of research conducted by Hidayah (2016) which states that compensation has a positive effect on employee performance, so that the better the compensation system of a company, the employee's performance will also increase. On the other hand, the results of this study reject the results of research conducted by Arifin (2017) which states that compensation does not have a significant effect on employee performance.

\section{Effect of Organizational Culture on Employee Performance}

The test results and statistical calculations of the influence of Organizational Culture (X2) on the Performance variable (Y2) show $\mathrm{t}_{\text {count }}$ of 10.992, the p-value is 0,000 and the path coefficient (beta) is 0.858 . The results of the $t$ test illustrate that $t$ count is greater than $t_{\text {table }}(10,992>2,000)$. Based on the p-value where the calculation results show that the p-value is smaller than the significance value $(0,000<0,05)$ and the calculated $t$ value is greater than $t_{\text {table }}$. and the p-value is smaller than the significance value and the value of the path value coefficient (beta) has a positive number, so the results are significant. These results can be concluded, indicating that the Performance variable (Y2) is positively and significantly influenced by the organizational culture variable (X2).

Based on the results of these studies, it is known that the better the organizational culture that is owned by an agency, the performance owned by employees will also increase. This is because performance is the overall ability of a person to work in such a way as to achieve work goals optimally, to achieve optimal work results then an employee certainly requires the cooperation of other employees around him so that the goals of the employee can be resolved properly.

The results of this study support the results of research conducted by Rantesalu et al (2016) which states that Organizational Culture influences Employee Performance. On the other hand, the results of this study reject the results conducted by Maabuat (2016) which states that organizational culture does not affect employee performance. 


\section{E. Effect of Compensation on Job Performance and Satisfaction}

The results of statistical calculations show that the Compensation variable has a significant effect on the Satisfaction variable with a coefficient of 0.570 . The Compensation variable also has a significant effect on the Performance variable with a coefficient of 0.159. Indirect test shows that the compensation variable has a coefficient of 0.063 which indicates that the compensation variable has a significant effect on employee performance through the variable job satisfaction.

Compensation is very important for employees as individuals, because the amount of compensation is a reflection or measure of the value of work. Conversely, the size of compensation can affect employee performance and employee job satisfaction (Handoko, 2012). From the statement above it can be concluded that compensation has a relation to job satisfaction.

Every organization should strive to increase the work satisfaction of its employees by providing fair and decent and competitive compensation programs. This is in line with the opinion of Siagian (1997) which states that organizations should be able to make a compensation system that can encourage job satisfaction for their employees, which in turn will form a positive and productive attitude. According to Madura (2001) factors that can influence job satisfaction include fair and decent compensation programs, job security, flexible work schedules, and employee engagement programs. Satisfaction with compensation is determined by fair compensation, compensation rates, and compensation administration practices.

Employee satisfaction can be seen from the willingness of the employee to work. Willingness or high employee motivation can be understood that the employee has a feeling of satisfaction that is also high. Meanwhile the company can increase employee motivation by providing compensation. Employees who are given high compensation will feel their performance is appreciated. These feelings can then lead to satisfaction in work because they have received an appropriate award, then later the employee is more motivated to improve the quality of his performance.

This result reinforces the research conducted by Anoki Herdian Dito (2010) regarding the effect of compensation on employee performance with positive and significant influences. In the research of Rani Mariam (2009) regarding leadership style and organizational culture that positively influences employee performance through employee job satisfaction is positively influential. Agencies need to pay attention to the level of job satisfaction for good employee performance in the agency. In addition, it is stated that other factors in the provision of understanding and appreciation of employees by providing promotional opportunities, as well as opportunities to participate and be involved in any related decision making are also important.

\section{F. Effect of Organizational Culture on Employee Performance Through Employee Job Satisfaction}

The results of statistical calculations show that the organizational culture variable has a significant effect on the Satisfaction variable with a coefficient of 0.570. The Compensation variable also has a significant effect on the Performance variable with a coefficient of 0.858 . Indirect test shows that the compensation variable has a coefficient of 0.063 which indicates that the compensation variable has a significant effect on employee performance through the variable job satisfaction.

Human resources is one of the factors that have an important role in efforts to improve the quality and performance of the company in order to achieve the objectives of the company. High and low performance of human resources will have an impact on overall organizational performance (Gibson in Octaviana, 2011: 5). So as to improve company performance, employees need to improve their performance first. If in an organization has employees that produce poor performance, it will result in the company's goals will not be achieved, on the contrary if employees can produce good performance, then the company's goals will be achieved. Performance is defined by Mangkunegara (2012: 67) as a work of quality and quantity achieved by an employee in carrying out his duties in accordance with the responsibilities given to him. Many factors influence employee performance, one of which is through organizational culture.According to Flippo (2010: 14) the factors that influence employee performance are motivation, job satisfaction, leadership, work climate, organizational culture, work discipline, and employee capabilities (education and training). If employees are given an 
understanding of organizational culture, then each employee will be motivated to perform each of the tasks assigned by the company. Employees who have high work motivation, work production will increase, it will produce optimal work performance.

Robbins (2003: 699) states that a strong organizational culture gives employees a clear understanding of the tasks given by the organization, and has a large influence on the behavior of its members because of the high level of togetherness. Many research experts show that organizational culture can be the basis of adaptation and the key to organizational success. With the creation of a good organizational culture, it will bring employees to the authority of the company where they work. This will bring an employee to give maximum performance to the work he does. Job satisfaction generally concerns a person's attitude about his job. Individuals with job satisfaction are expected to spend all their abilities and energy to complete the work, so that they can produce optimal performance for the company.

Employee job satisfaction is closely related to the attitudes of employees towards psychological factors, physical factors, social factors, and financial factors. There are aspects in the values of corporate culture that are able to meet employee expectations, so that employees and members of the organization get job satisfaction in their work. These aspects can be in the form of highly valued innovations in the corporate culture, appreciation of the similarity of degrees among all employees and also the values of the relationship between leaders and subordinates who are not discriminatory. This is what shapes organizational culture.

From the explanation above, improving employee performance can be done by building a healthy organizational culture through increasing job satisfaction. The results of Schein's (1989) study show that organizational culture is beneficial for individual workers, for example in paying attention to individuals and oriented to achievement, justice and sportsmanship. Then it can be expected that there will be better job satisfaction than before. This is similar to the results of research by Mustika (2013) which states that organizational culture has a significant influence on employee performance through job satisfaction variables as an intervening variable. These three variables are interconnected and have significant influence on each other. This study also supports the results of research conducted by Baskoro (2013), which shows the results that organizational culture has a direct (direct) influence on job satisfaction and motivation. In addition there are also influences on employee performance through job satisfaction. This arises from the existence of good relations between superiors and subordinates can be established well by holding a forum between superiors and subordinates held regularly.

\section{CONCLUSION}

Based on the results of the research and discussion, conclusions were obtained in the study as follows:

1. Employee satisfaction has a significant effect on the compensation system, where the better the compensation system applied to an agency, the greater job satisfaction will be.

2. Organizational culture has a significant influence on satisfaction, where the better the organizational culture possessed by an agency, the greater job satisfaction will be.

3. Compensation has a significant effect on employee performance, where the better the compensation applied to an agency, the better the employee's performance.

4. Organizational culture has a significant influence on employee performance, where the better the organizational culture that is owned by an agency, the performance of employees will also increase.

5. Compensation has a significant influence on employee performance through employee performance satisfaction at the Tk Hospital. II dr. Soepraoen .

6. Organizational culture has a significant influence on employee performance through employee performance satisfaction at the Hospital. II dr. Soepraoen . 


\section{SUGGESTION}

1. Hospital: the management pays attention to satisfaction, employee performance, characteristics of the compensation system and organizational culture, so that the health services at Dr. Soepraoen's Second Class Hospital increase and also the quality of service as long as patients receive care .

2. Next researcher: the development of science in the field of hospital administration and as a basis for developing research on employee satisfaction and performance in hospitals and can find out the basis of data processing in research .

\section{REFERENCES}

AA. Mangkunegara, A., P. (2013). Manajemen Sumber Daya Manusia Perusahaan. Bandung: PT Remaja Rosdakarya.

Ahmad, N., Iqbal, N., Kanwal, R., Javed, H., \& Komal, J. (2014). The mediating role of employee engagement in relationship of internal branding and brand experience: Case of service organization of Dera Ghazi Khan. International Journal of Information, Business and Management.

Burhan, \& Bungin. (2013). Metode Penelitian Kuantitaif. Jakarta: Kencana.

Handoko, \& T., Hani. (2015). Manajemen Personalia dan Sumber Daya Manusia. Yogyakarta: BPFE.

Kuncoro, A., Engkus, \& Riduwan. (2014). Cara Menggunakan dan Memakai Analisis Jalur. Bandung: Alfabeta.

Mathis, Robert, L., \& Jackson, J., H. (2013). Manajemen Sumber Daya Manusia. Buku 1, Alih Bahasa: Jimmy Sadeli dan Bayu. Prawira Hie. Salemba Empat. Jakarta.

Robbins, Stephen, P., Judge, T., A. (2013). Perilaku Organisasi, PT. Salemba Empat, Jakarta.

Sadili, \& Samsudin. (2016). Manajemen Sumber Daya Manusia. Bandung: Pustaka Setia.

Susanty, \& Etty. (2017). Pengaruh Iklim Organisasi terhadap Kepuasan Kerja dan Komitmen Karyawan pada Universitas Terbuka. Jurnal Organisasi dan Manajemen, Volume 8, Nomor 2, hlm. 121-134.

Wayne, R., Mondy \& Martocchio, J., J. (2016). Human Resource Management. United States Of America: Pearson Education Limited.

Wirawan. (2013). Budaya dan Iklim Organisasi. Jakarta. Salemba Empat. Undang- undang Rumah Sakit Nomor 44 tahun 2009. 